\author{
JAGNA MALEJKA \\ (D) https://orcid.org/0000-0001-6545-7675
}

Shanghai International Studies University

Shanghai

\title{
Wykorzystanie podejścia międzykulturowego w nauczaniu języka polskiego w Chinach na przykładzie kuchni
}

Jedzenie jest niebem ludu (民以食为天)

S i m a $\mathrm{Q}$ i a n, Zapiski historyka, 90 r. p.n.e.

Using an intercultural approach in teaching Polish in China using the example of cuisine

\begin{abstract}
The paper presents aspects related to the use of an intercultural approach in teaching Polish as a foreign language in China. It focuses on cuisine and food in general. Effective communication requires not only grammatical rules and vocabulary to be mastered, but also knowledge of the rules that prevail in the interlocutor's country, of the sociolinguistic and sociocultural determinants. The sample material comes from the author's collections built during her work at Asian universities. An intercultural approach in teaching Polish linguistic and cultural behaviours in China requires different practices and solutions than those applied in the European cultural circle.
\end{abstract}

Keywords: Polish studies in China, sociocultural, sociolinguistic, intercultural

Podejście międzykulturowe, polegające na kontrastywnym odwoływaniu się do zachowań socjolingwistycznych i socjokulturowych przyjętych w kraju osób uczących się języka obcego oraz w kraju języka nauczanego $^{1}$, ma już swoje stałe miejsce w glottodydaktyce ${ }^{2}$.

1 „Podejście międzykulturowe, kojarzone z procesem jednoczenia się Europy, na pierwszy plan wysunęło uzyskanie tzw. kompetencji międzykulturowej, czyli zdolności do porozumienia między członkami różnych kręgów kulturowych i narodów; umiejętności budowania tzw. mostów porozumienia" (Gębal 2004a, 72).

2 Zob. m.in. Gębal 2004a; 2004b; Janowska i in. 2016; Miodunka 2004; Morcinek 2010; Tambor 2015; Zarzycka 2008 i 2018; Żydek-Bednarczuk 2015. 
Warunkiem skutecznej komunikacji w obcym języku jest bowiem nie tylko opanowanie słownictwa i gramatyki. Niemniej ważna jest szeroko pojęta kompetencja kulturowa, na którą składają się: znajomość realiów kraju języka przyswajanego, opanowanie reguł społecznych w nim obowiązujących, zachowań werbalnych i niewerbalnych związanych z różnymi sytuacjami, grzeczności językowej itp.

warto wykorzystać do budowania kompetencji kulturowej te obszary, które związane są z kompetencją socjokulturowa, strategiczną i kompetencją dyskursu. Gdybyśmy połączyli teraz wiedzę proceduralną z systemową moglibyśmy zbudować model kompetencji komunikacyjnej dla obcokrajowca. Obejmowałby zarówno wiedzę i umiejętności gramatyczne, znajomość reguł tworzenia i organizacji dyskursu, kompetencję funkcjonalną, jak i kompetencję socjolingwistyczna, czyli socjalną i kulturową (Żydek-Bednarczuk 2015, 69-70).

Dopiero wykształcenie ,interkulturowego rozmówcy”3, umiejętność połączenia wszystkich tych elementów stanowi podstawę zadowalającego obie strony porozumienia. Grażyna Zarzycka pisze:

definiuję podejście interkulturowe jako pedagogikę zorientowaną na rozwój kompetencji i wrażliwości interkulturowej, empatii, zrozumienia dla inności, jako pedagogikę dialogu i wewnętrznego rozwoju. Celem tak rozumianej dyscypliny jest kształtowanie interkulturowego rozmówcy (...). Trudno sobie jednak wyobrazić nauczanie jakiegokolwiek języka, w tym także jpjo, w którym komponent interkulturowy byłby całkowicie nieobecny (Zarzycka 2018, 534, 538-539).

Ogólnie pojęte treści kulturowe możemy podzielić na: zagadnienia socjolingwistyczne i socjokulturowe oraz realioznawcze (por. m.in. Jelonkiewicz 2004, 38, 48; Miodunka 2004, 103-104; Janowska i in. 2016).

Artykuł stanowi część projektu poświęconego opisowi nauczania międzykulturowego na Dalekim Wschodzie. Przedstawiam w nim wybrane zagadnienia dotyczące wykorzystania podejścia międzykulturowego w nauczaniu języka polskiego w Chinach. Wstęp do badań oraz zagadnienia związane z formułami powitań, pożegnań, pozdrowień oraz wybranymi formami ad-

3 Według Grażyny Zarzyckiej „,kompetentny interkulturowy rozmówca to ktoś, kto nie tylko odczuwa przyjemność z komunikowania się z innymi, lecz również ma wrażenie odpowiedniości, poprawności i skuteczności danej wymiany komunikacyjnej” (Zarzycka 2018, 535). 
resatywnymi przedstawiłam w artykule pt. Podejście międzylkulturowe w nauczaniu jezyka polskiego jako obcego w Chinach (w druku). Podstawę teoretyczną opisu stanowia pozycje poświęcone nauczaniu kultury polskiej w Europie i bliższych jej kręgach kulturowych oraz prace powstałe na polonistykach dalekowschodnich. Zaprezentowane przykłady pochodzą z materiału zebranego przeze mnie podczas pracy na uniwersytetach w Chinach $^{4}$.

Tzw. „minimum kulturowe” jest już obecne w programach nauczania języka polskiego jako obcego (Janowska $\mathrm{i}$ in. 2016) ${ }^{5}$. Zostało ono wyznaczone dla każdego poziomu, chociaż nadal określa się je mianem „propozycji” (w przeciwieństwie do gramatyki, leksyki itd., gdzie wymogi są dużo bardziej rygorystyczne). Dla każdego poziomu przedstawiono katalog zagadnień, poprzedzony krótkim wstępem:

Proponowane zagadnienia socjolingwistyczne, socjokulturowe i materiał realioznawczy należy traktować jako program minimum. Trzeba być jednak otwartym na potrzeby uczących się pojawiające się spontanicznie podczas zajęć, a także przygotowanym do realizacji tematów wykraczających poza niniejszy program (Janowska i in. 2016, 24, 53, 86, 121, 158, 194).

Nauczanie języka polskiego i kultury polskiej w odległych kręgach kulturowych wymaga przełożenia punktów ciężkości, wyboru innych treści lub też ułożenia ich w odmiennej kolejności niż w przypadku pracy w krajach słowiańskich, w ogóle europejskich, czy tych z częściowym chociaż europejskim dziedzictwem kulturowym. Zakres zagadnień socjolingwistycznych i socjokulturowych musi być szerszy, a kontrastów powinno być więcej niż odwołań do rodzimej kultury studentów (por. Miodunka 2004, 104-105).

Lektor języka polskiego, podejmujący pracę na uniwersytetach dalekowschodnich, bardzo szybko orientuje się, że różnice kulturowe dotyczą niemal każdego aspektu życia społecznego: form nawiązywania kontaktu, przedstawiania się, powitań i pożegnań, przechodzenia na ty (jeśli w ogóle), komplementowania, dystansu między rozmówcami, mimiki i gestów, mowy ciała, ubioru, sposobów spędzania wolnego czasu, obchodzenia świąt i uro-

${ }_{4} \mathrm{Na}$ Pekińskim Uniwersytecie Języków Obcych (Beijing Foreign Studies University) w latach 2005-2011 oraz na Szanghajskim Uniwersytecie Studiów Międzynarodowych (Shanghai International Studies University) od 2019 roku.

5 Wyznaczone minimum kulturowe jest stosunkowo nowe. Jeszcze w 2004 roku Przemysław Gębal pisał: „Wszelkie ustalenia maja raczej charakter umowny. Nie określono, jak w przypadku gramatyki, tzw. minimum kulturowego, jakim powinien dysponować uczacy się języka cudzoziemiec” (Gębal 2004a, 70). 
czystości rodzinnych, relacji w rodzinie, zasad funkcjonowania w społeczeństwie, grzeczności językowej i kultury osobistej, a także kuchni i związanych z nią rytuałów społecznych ${ }^{6}$. Oczywiście różnice w wymienionych sferach życia obserwujemy przy każdym zetknięciu się z obcą kultura, a nawet z mieszkańcami różnych regionów jednego kraju, jednak w kontakcie z odległymi - geograficznie i kulturowo - miejscami kontrasty te nabieraja ostrości. Jeśli występujemy w roli turysty czy gospodarza, możemy je tylko obserwować lub starać się poznać i zrozumieć; pozycja nauczyciela/lektora stawia jednak zupełnie inne wymagania - zwłaszcza w przypadku wyjazdu do innego kraju i nauczania własnej kultury na tamtym terenie.

Przemysław Gębal w artykule poświęconym realioznawstwu w nauczaniu języka niemieckiego zwraca uwagę na wykorzystanie różnych metod w zależności od miejsca nauki: nauczanie w kraju docelowym, w którym uczący się mają na co dzień kontakt z językiem i kultura; nauczanie w kraju sąsiadującym, gdzie ważną rolę odgrywają kontakty przygraniczne; „nauczanie w pozostałych krajach - im dalej od kultury docelowej, tym mniejsza możliwość bezpośrednich kontaktów" (por. Gębal 2004a, 92). W tym miejscu skupimy się na trzeciej możliwości, czy raczej konieczności - nauczaniu języka polskiego i kultury polskiej na terenie Chin?

Jak już wspomniałam, różnice kulturowe dotyczą niemal każdego aspektu życia, jednak kilka wydaje się szczególnie ważnych, zwłaszcza dla lektora przyjeżdżającego do Chin ${ }^{8}$. Jedną z najważniejszych, a tym samym najciekawszych, jest rola kuchni i w ogóle jedzenia, a także organizacji chińskiego życia wokół jedzenia9. Bardzo istotne jest zrozumienie wagi tego zagadnienia, poznania zwyczajów żywieniowych studentów, aby dzięki temu (przez

6 Porównaj: Katalog zagadnień socjolingwistycznych, socjokulturowych $i$ realioznawczych (Janowska $\mathrm{i}$ in. 2016, 24-25, 54-55, 86-87, 121-122, 158-159, 194-196).

7 Pierwsza polonistyka w Chinach powstała na początku lat 50. ubiegłego wieku na Pekińskim Uniwersytecie Języków Obcych; przez kilkadziesiąt lat była jedynym miejscem w tym kraju, gdzie można było uczyć się języka polskiego. Po 2008 roku zainteresowanie językiem polskim bardzo wzrosło; dziś można go poznać w kilkunastu ośrodkach akademickich na terenie całego kraju. Obecnie 14 uczelni oferuje kształcenie z zakresu języka polskiego, w tym 11 - studia licencjackie $z$ kierunkowym polskim.

8 O wyzwaniach czekających na lektorów w Japonii i Korei pisali m.in. Lisowski 2006; Morcinek 2010; Choi 2018.

9 Aby nawiązać do wspomnianego wyżej przełożenia punktów ciężkości, wyboru innych treści i kontrastów niż w krajach np. słowiańskich, proponuję zestawienie z pracami poświęconymi nauczaniu w Słowenii - na przykładzie kuchni (Wacławek, Wtorkowska 2018a; 2018b). 
ciagłe odwołania i kontrasty) móc przybliżyć na zajęciach odpowiedni aspekt kultury polskiej. Jak pisze P. Gębal: „Kompetencja międzykulturowa ułatwia lepsze zrozumienie nie tylko kultury obcej, ale i własnej, gdyż ta druga również jest obecna na każdych zajęciach z języka obcego" (Gębal 2004a, 73).

Zdaniem mieszkańców Państwa Środka kuchnia chińska jest najlepsza na świecie. Jednak jedzenie jest dla nich czymś więcej niż dla znanych mi przedstawicieli innych nacji. Jest istotą życia, jego centrum ${ }^{10}$. Stare chińskie powiedzenie mówi: „Jedzenie jest niebem ludu”.

Godziny posiłków są ściśle przestrzegane i nikt z własnej woli z żadnego z nich nie zrezygnuje. Południe to czas obiadu, w każdym miejscu pracy i nauki przewidziana jest wtedy przerwa. Sąsiad zainteresuje się tym, co spotkana osoba niesie w siatce, ale nie ze zwykłego wścibstwa, tylko żeby wspólnie porozważać, co i w jaki sposób można ugotować z zakupionych produktów. Najpierw jednak zapyta rozmówcę o to, czy już zjadł poprzedni posiłek $^{11}$. Każda okazja obchodzona jest przy suto zastawionym stole, bardzo często w restauracji. Liczba, różnorodność przygotowanych/zamówionych potraw świadczy o zamożności gospodarza/zapraszającego. Chińczycy przemierzają nieraz pół miasta (co czasami zajmuje kilka godzin), żeby zjeść w wybranym punkcie gastronomicznym; wykazują się też nie lada cierpliwością, kiedy stoją dosyć długo w kolejce (znowu - nawet kilka godzin), by w ogóle wejść do środka. Bogactwo chińskiej kuchni jest niewyobrażalne, a w wielkich miastach, takich jak Pekin czy Szanghaj, można spróbować potraw z każdego regionu. Studenci chińscy nie idą z kolegami na piwo, idą do restauracji (co nie jest luksusem, jak w przypadku polskich studentów). Chińczycy wyjeżdżający na stypendium za granicę zabierają ze sobą garnek do gotowania ryżu, przyprawy i inne niezbędne składniki potrzebne w kuchni, często kosztem miejsca na ubrania. Podczas pobytu w obcym kraju gotuja chińskie potrawy, kiedy tylko jest to możliwe.

Pomijając ogólne różnice kulinarne między naszymi krajami, warto wspomnieć o organizacji życia studenckiego, które ma także ogromny wpływ na

10 Badając kilka lat temu autostereotyp Chińczyków, przeprowadziłam ankietę, w której m.in. pytałam o kuchnię. Najczęściej pojawiały się takie odpowiedzi: „Jedzenie to kultura; kultura kulinarna jest chińskim bogactwem; jedzenie jest podstawą życia Chińczyków; jest najważniejsze; to zdrowie; źródło energii życiowej; ważny relaks; o wszystkim można porozmawiać i wszystko załatwić przy stole” (Malejka 2008, 221-222).

11 Pytanie „Czy już zjadłeś?” jest formą pozdrowienia, powitania. Choć przez niektórych uważane za nieco już przestarzałe (Li 2012, 264), nadal jest bardzo często zadawane. 
odżywianie się. Studenci chińscy mieszkają w akademikach na terenie kampusu; dotyczy to wszystkich, nawet mieszkańców zameldowanych w mieście, w którym znajduje się ich uczelnia. Wynika to nie tylko z dosyć dużych odległości, które dzielą miejsca zamieszkania od uniwersytetów, ale także z tradycji akademickiej. Młodzi ludzie mają do dyspozycji stołówki - również wymykające się naszemu rozumieniu tego miejsca. Są to wielopiętrowe instytucje, oferujące rozmaite potrawy w różnych cenach; spożywane są tam często wszystkie posiłki w ciagu dnia. W ostatnich latach ogromna popularność zyskało zamawianie jedzenia przez Internet, z czego wielu korzysta. Czasem studenci wychodzą do restauracji oferujących kuchnię zagraniczną, jednak większość koncentruje się głównie wokół chińskiego jedzenia. Mimo nieprzebranej oferty zachodnich restauracji w takich metropoliach, jak Pekin czy Szanghaj, Chińczycy chodzą do nich stosunkowo rzadko, raczej z ciekawości. Bo tak naprawdę nie ma lepszego jedzenia od chińskiego. Marcin Jacoby, wybitny polski sinolog, pisze:

Dla człowieka wychowanego na zupie pomidorowej, naleśnikach i okazjonalnej zapiekance ta fascynacja jedzeniem może okazać się zupełnie niezrozumiała, a czasem i nużąca. Nieraz zastanawiałem się, czy dla Chińczyków jest coś ważniejszego niż jedzenie. Po latach dochodzę do ostrożnego wniosku, że chyba nie (Jacoby 2016, 307).

Cudzoziemski nauczyciel chińskich studentów powinien jak najszybciej pogodzić się z tym, że nie ma dla nich niczego ważniejszego niż jedzenie i odpowiednio przygotować się do prezentacji zwyczajów kulinarnych własnego kraju.

Jednak nie tylko różnorodność potraw stanowi odmienność kuchni chińskiej od, na przykład, polskiej. Inne są pory jedzenia posiłków, sposoby ich podawania, kolejność spożywania, sposób jedzenia. W procesie nauczania ta kwestia pojawia się bardzo szybko i pilnie należy problem rozwiązać. W przypadku pracy ze studentami chińskimi kultura kulinarna jest - moim zdaniem - najbardziej wymagającym obszarem, jeśli chodzi o nauczanie zachowań socjolingwistycznych i socjokulturowych; wymaga ciagłego kontrastywnego zestawiania treści, międzykulturowego dyskursu, prób zrozumienia, kształtowania wzajemnego szacunku, otwartości i tolerancji. Bardziej niż na jakimkolwiek innym polu ważna jest tu znajomość zwyczajów panujących w Państwie Środka.

Poniżej przytoczę kilka najistotniejszych w moim odczuciu różnic, które bardzo szybko pojawiają się w cyklu dydaktycznym i których nie można (bez szkody dla tegoż) pominąć. 


\section{Pory jedzenia posiłków}

Godziny spożywania śniadań są zbliżone, czyli godziny poranne przed wyjściem do pracy, szkoły, na uczelnię. Różnica jest wyraźna przy obiedzie. Jak wspomniałam, w Chinach jest to południe i wynikająca $z$ tego przerwa w pracy czy w lekcjach/zajęciach. W Polsce sa to godziny 14-16, czasem nawet późniejsze, związane z powrotem do domu po pracy. W ostatnich latach to się zmienia, Polacy również pracują dłużej i coraz częściej jedzą drugi główny posiłek poza domem, jednak rzadko się zdarza, żeby ktoś szedł na obiad o $12^{12}$. Nie pamiętam sytuacji, w której tę informację studenci przyjęliby bez emocji. Spożycie pokarmu w południe daje bowiem siłę i energię na cały dzień i niewyobrażalne jest, aby przez tyle godzin chodzić głodnym. Ta różnica kulturowa prowadzi nawet do błędnego rozwiązywania ćwiczeń polegających na ułożeniu planu dnia ${ }^{13}$.

Kolacja przypada na porę mniej więcej od godziny 18, jest to często najważniejszy posiłek, najbardziej obfity, przy którym w domach lub restauracjach spotyka się cała rodzina lub znajomi.

\section{Skład posiłków i sposoby ich spożywania}

Chińczycy większość produktów poddają obróbce cieplnej i bardzo rzadko jedzą coś surowego lub zimnego, jak np. sałatki czy kanapki. Te ostatnie to jedynie przejaw mody, niewzbudzający jednak szczególnego entuzjazmu. Dlatego też tutejsze śniadania różnią się bardzo od polskich. Studenci zapytani o to, co przeważnie jedzą na śniadanie, najczęściej odpowiadaja: makaron, naleśniki (w wersji chińskiej), bułki na parze, nadziewane bułki na parze, kleik ryżowy, mleko sojowe, jajka (gotowane lub sadzone), bataty, kukurydzę, marynowane warzywa. Na obiady i kolacje składają się podobne

\footnotetext{
12 Jolanta Tambor zadaje nawet pytanie, czy obiad o godzinie 14.00 jest polskim kulturemem - relewantnym elementem kultury o cechach dystynktywnych, pozwalającym wyróżniać istotne elementy składowe danej kultury (Tambor 2018, 205-206). Bez wattpienia obiad w samo południe jest kulturemem chińskim; widać to wyraźnie w samej warstwie leksykalnej. Obiad to po chińsku 午饭 (mǔfàn) 'posiłek w południe'. Śniadanie i kolacja sa odpowiednio 'posiłkiem rano'(早饭, zăofàn), 'posiłkiem wieczorem' (晚饭, wănfàn).

13 Przykład ten opisałam dokładnie w artykule Na głeboka wode - o zaletach (i wadach) komunikowania sie z. Chincsykami wytacznie po polsku (Malejka 2010, 174).
} 
potrawy, główna różnica polega na tym, czy je się samemu czy w towarzystwie. Dla osób, które z konieczności musza jeść same (podkreślam, że jedzenie ma ogromne znaczenie $w$ relacjach międzyludzkich, ale nie zawsze jest możliwe biesiadowanie), restauracje, jadłodajnie i stołówki przedstawiaja nieprzebraną ofertę posiłków jednodaniowych, np. ryż/makaron z różnymi dodatkami, zupy z makaronem lub pierożkami, pierogi z rozmaitym nadzieniem, placki i wiele innych. Ucztowanie ze współbiesiadnikami łączy się z zamówieniem kilku potraw: mięsa, ryb, warzyw, tofu, owoców morza, zup, którymi biesiadujący dzielą się, korzystając z ustawionych na stole półmisków i talerzy. To oczywiście opis podany w ogromnym uproszczeniu, bo można jeszcze gotować we wspólnym goracym kociołku czy opiekać na grillu, jeść szaszłyki, pierogi itd., z radością się dzielić i domawiać coś od czasu do czasu. Wszystko jest jedzone pałeczkami, większość chińskich restauracji nadal nie ma w wyposażeniu sztućców. Nawet łyżki nie są wszędzie dostępne, ponieważ zupę pije się z małych miseczek, a ciecz pozostającą z jednodaniowej zupy z makaronem - prosto z dużej miski. Także estetyka jedzenia jest zupełnie odmienna od europejskiej. Ostatnio się to zmienia, jednak „nabrudzenie”, zachlapanie obrusu czy odłożenie kości i ości na stół obok talerza nie jest niczym niewłaściwym. Radości wspólnie spożywanego posiłku nie moga zakłócić takie drobiazgi. Ostatnia kwestia jest bardzo istotna w nauczaniu kultury - lektor powinien uświadomić studentom, że takie zachowanie jest w Polsce niewłaściwe, należy jednak przy tym bardzo uważać, by studentów nie obrazić. Nie możemy utożsamiać odmienności kultury z jej brakiem. Wszyscy wychodzimy z założenia, że ,jeżeli u nas tak się coś robi, mówi, to tak jest dobrze, i tak powinni postępować inni” (Marcjanik 2008, 22). W tym miejscu bardzo uwidacznia się waga roli nauczania międzykulturowego i odwołania do kontrastów.

\section{Dania główne a dodatki}

W języku chińskim ryż, makaron, bułki na parze ${ }^{14}$ nazywane są „głównym jedzeniem” lub „podstawowym pożywieniem” (zhǔ shí,主食). Ziemniaki są dla Chińczyków zwykłym warzywem, nie stanowia podstawy czy uzupełnienia dania obiadowego; nie są też spożywane wyjątkowo często. Chleb jest

14 Rodzaj „głównego jedzenia” i jego frekwencja w diecie zależy od regionu. Na północy spożywa się znacznie więcej potraw mącznych, a na południu - ryżu. 
rodzajem ciasta i kupuje się go w cukierni lub kawiarni, równie rzadko jest podstawowym składnikiem posiłku.

W przykładowym menu polskiej restauracji chiński student znajdzie ž̧̧u shi pod nazwą „dodatki”. Karty „dania główne” czy też „drugie dania” bez wiedzy socjolingwistycznej nie zostaną zrozumiane, bo dla Chińczyków nie są ani główne, ani drugie. Polski jadłospis ulega zresztą w ostatnich latach przemianom, co może stanowić dodatkowe komplikacje. Jolanta Tambor pisze:

Obiady już nie tak często, nawet w niedzielę, składają się z trzech czy choćby dwóch dań. Dawniej polskie posiłki obiadowe dzieliły się na:

- pierwsze danie, czyli zupę,

- drugie danie, czyli właściwe danie, które w razie czego mogłoby być samodzielne,

- deser.

Ślady takiego podziału nadal są widoczne w języku, gdyż można usłyszeć wypowiedzi: „co podać na pierwsze, a co na drugie?”. Dziś częściowo trzeba zmienić znaczenie tych wyrażeń czy liczebnikowych elips. Pytanie „co na pierwsze?” oznacza typ dania podawanego przed drugim daniem, coraz częściej zresztą nazywanego, na pewno w restauracyjnych menu, bo wcale niekoniecznie w języku potocznym, daniem głównym. Owym pierwszym mogą być zarówno przystawki / przekąski / zakąski / entrées / starters (najsłabiej przyjęła się w polszczyźnie kulinarnej nazwa appetizers), jak i zupy. Kiedyś oznaczało tylko zupy (Tambor 2018, 206).

Ten może nieco długi (aczkolwiek bardzo skromny) opis zwyczajów kulinarnych Chińczyków ma na celu przybliżenie wagi tematu i ogromu pracy oraz wyzwań, które czekają lektora przybywającego do Chin. Jeśli naprawdę chcemy przekazać chińskim studentom wiedzę o polskiej kuchni, musimy najpierw okazać szacunek dla ich tradycji kulinarnej i rytuałów ${ }^{15}$ z nią związanych, a następnie kontrastywnie zestawić ją z nasza, podkreślając wagę wzajemnej akceptacji, tolerancji i obustronnego zrozumienia.

Należy w tym miejscu zwrócić uwagę na bardzo istotną kwestię. Jednym z naszych głównych zadań jest oczywiście przybliżenie kultury polskiej. Jednak nie mniej ważne jest nauczenie studentów opowiadania o własnym

15 Zagadnienia związane $\mathrm{z}$ towarzyszącymi jedzeniu rytuałami: zapraszaniem, częstowaniem, akceptacją i odmowa, toastami, miejscem zajmowanym przy stole, płaceniem rachunków, adekwatnością ubioru do miejsca spotkania itp. są ogromnie ważne w nauczaniu międzykulturowym, jednak ze względu na obszerność tematu wymagają oddzielnego opisu. 
świecie i przedstawianie w języku polskim ich rodzimej - w tym przypadku chińskiej - kultury.

Cały czas przeplatają się dwa cele: 1) uczący się musi umieć opisać swój świat - choćby dlatego, że jest to interesujące dla osób poznawanych w kraju, którego języka się uczy, czy władających tym językiem, przyjeżdżających do kraju uczącego się; 2) uczący się musi umieć opisać świat poznawanego języka, by móc o nim opowiedzieć swoim bliskim - wiemy, iż robi to raczej w rodzimym języku, jednak nauka obcego języka ma mu pomóc w nazywaniu realiów właśnie (Tambor 2015, 85).

Jedzenie, jak wiadomo, pojawia się dosyć szybko w programach nauczania. Na przykład w podręczniku Hurra! Po polsku 1 jest to lekcja 6, w podręczniku Krok po kroku 1 - lekcja 8, w podręczniku/programie Po polsku po Polsce stacja 3. Bohaterowie wymienionych książek na różne sposoby przedstawiaja rozmaite produkty spożywcze, a następnie komponuja tradycyjne polskie śniadania, obiady i kolacje. Wymieniane są: chleb, bułka, masło, szynka, kiełbasa, ser żółty, ser biały, dżem, miód, płatki śniadaniowe, jajecznica, omlet itd. Do tego kilka dań obiadowych: pomidorowa, żurek, barszcz, kotlet (schabowy), kurczak, ziemniaki, sałata, różne rodzaje pierogów i inne. $\mathrm{Na}$ kolację też można zrobić kanapkę z produktów poznanych przy okazji przygotowywania śniadania. Podane są także przybliżone godziny posiłków. Ucząc języka polskiego w Chinach (w ogóle na Dalekim Wschodzie), doświadczamy w tym momencie prawdziwego szoku kulturowego. Dotyczy to wszystkich: i studentów, i nauczycieli. Przedstawienie i wytłumaczenie podopiecznym polskich zwyczajów żywieniowych wymaga długiego wykładu z dobra prezentacją multimedialną, można to jednak zrealizować. Natomiast w momencie, w którym dochodzimy do aktywnego wykorzystania poznanych słów i konstrukcji (np. Co jesz. na śniadanie? Jem chleb z. mastem, szynka i serem; Co pijesz do śniadania? Pije herbate z cukrem i z cytryna), możemy liczyć albo na sztuczną konwersację polegającą na powtarzaniu zdań z podręcznika, albo na spektakularną klęskę - ponieważ chiński student nie je kanapek na śniadanie, chyba że te kupione w Starbucksie lub w innej z pojawiających się coraz liczniej kawiarni w stylu zachodnim, a i te raczej nie na śniadanie. Obiady i kolacje różnią się jeszcze bardziej. Tak więc Chińczycy na początku swojej nauki nie są w stanie po polsku powiedzieć, co tak naprawdę jedzą. Tym bardziej, że nazewnictwo chińskich potraw czasem odbiega od ich rze- 
czywistego składu czy procesu przygotowania. Często są to nazwy zwyczajowe, metaforyczne, poetyckie ${ }^{16}$. Pozostaje przedstawienie opisowe $z$ wykorzystaniem słownictwa nieraz z wyższego poziomu. Jest to konieczne, jeśli chcemy, by student opowiedział nam o swoim świecie ${ }^{17}$.

Propozycję takiego rozwiązania podaje Barbara Morcinek-Abramczyk w podręczniku do nauki języka polskiego dla osób japońskojęzycznych Polski jest prosty! Autorka, wykorzystując dwoje swoich bohaterów: Polkę i Japończyka, przedstawia na zasadzie kontrastu ich typowy dzienny jadłospis. W lekcji poświęconej jedzeniu ukazane zostało bogate słownictwo z zakresu nazw ryb, owoców morza, warzyw, produktów sojowych. Znajdziemy tam też kilka najczęściej spotykanych w Japonii potraw i przekąsek z krótkim opisem po polsku. Jest to książka dla początkujących, jednak zgadzam się z autorką, że dla Japończyków ogólne słowo „ryba” nie wystarczy nawet do podstawowego przedstawienia ich stylu odżywiania się ${ }^{18}$. Takie rozwiązanie umożliwia studentom na bardzo wczesnym etapie nauki naturalną konwersację w języku polskim.

Stopniowo możemy poszerzać zakres potrzebnego słownictwa i wracać do tematu. Pozwala na to sama konstrukcja procesu glottodydaktycznego i programów nauczania. W przedmowie do Programów nauczania jezyka polskiego jako obcego czytamy:

Programy nauczania języka polskiego jako obcego/drugiego oparte są na podejściu komunikacyjnym, stąd układ treści ma charakter spiralny. Przewiduje $\mathrm{w}$ związku z tym osiaganie wytyczonych celów dydaktycz-

${ }^{16} \mathrm{Na}$ przykład: 狮子头 (shī ẓ̌ tóu) 'lwie głowy' - duże klopsy; 蚂蚁上树 (mă y̌̆ shàng shù) 'mrówki wspinające się na drzewo' - smażony makaron ryżowy z mieloną wieprzowina; 佛跳墙 (fó tiào qiáng) 'Budda przeskakuje przez ścianę' - zupa z owoców morza z dodatkami, 松鼠桂鱼 (sōngsȟ̌ guì yû 'ryba wiewiórka' - ryba smażona w specjalny sposób, w efekcie czego przypomina ciemnopomarańczową wiewiórkę. Przykłady i tłumaczenie zostało zaproponowane przez moich obecnych studentów.

17 ,Jednym z przykładów dostrzegania potrzeby takiego podejścia w glottodydaktyce, czyli nazywania obcych realiów w języku polskim, są podręczniki do języka polskiego dla Japończyków czy Chińczyków - po erze zachłyśnięcia się podręcznikami uniwersalnymi, dla wszystkich, bez pośrednictwa języka-medium, zaczynamy wracać do idei podręczników «dedykowanych», kierowanych, adresowanych do konkretnych grup narodowych i językowych" (Tambor 2015, 84-85). O tej luce na glottodydaktycznym rynku wydawniczym zob. także Zarzycka 2018, 538.

18 Więcej na ten temat w artykule pt. Thumaczenie kultur - oswajanie kultur? Kilka uwag o kuchni (Morcinek 2010). 
nych poprzez ciagłe powracanie do tych samych treści oraz - wraz z rosnącym poziomem biegłości językowej uczących się - ich stopniowe rozszerzanie. Dlatego też np. te same funkcje komunikacyjne pojawiają się w całym procesie dydaktycznym (od A1 do C2), tyle że na wyższych poziomach nauczania wzbogacane sa o inne sposoby ich realizacji (Janowska $i$ in. 2016, 11-12).

Każdy lektor pracujący poza granicami swojego kraju potrafi z pewnością wyznaczyć pole, na którym musi się szczególnie skupić, umiejscowić na szczycie listy tematów do zrealizowania, zgłębienia, „przerobienia” na nowo i po raz kolejny. Inne kwestie są ważne w procesie nauczania Ukraińców, Czechów, Niemców, Francuzów czy Amerykanów, inne, gdy mamy do czynienia z Chińczykami, Koreańczykami czy Japończykami, inne jeszcze na Bliskim Wschodzie, inne w Indiach itd. W Chinach, a także w Korei i Japonii, takim obszarem semantycznym i socjokulturowym jest właśnie jedzenie $^{19}$, a podejście międzykulturowe daje najlepsze narzędzia do stworzenia mostów porozumienia i wzajemnego poznania się.

\section{Bibliografia}

Choi S-E., 2018, Znacrenie komunikacji miedryykulturowej w nauczaniu jesylka polskiego w Korei, w: Tambor J., red. całości, Polonistyka na poczatku XXI wieku. Diagnosy, koncepcje, perspektymy, t. V: Achtelik A., Graboń K., red., W kregu (glotto)dydaktyki, Katowice.

Gębal P.E., 2004a, Realioznawstwo w nauczaniu jezylka niemieckiego, w: Miodunka W.T., red., Kultura w nauczaniu jesyka polskiego jako obcego. Stan obecny - programy nauczania - pomoce dydaktyczne, Kraków.

Gębal P.E., 2004b, Program nauczania cudzoziemcón realión polskich, w: Miodunka W.T., red., Kultura w nauczaniu jesykea polskiego jako obcego. Stan obecny - programy nauczania - pomoce dydaktyczne, Kraków.

Jacoby M., 2016, Chiny bez makijażu, Warszawa.

Janowska I., Lipińska E., Rabiej A., Seretny A., Turek P., red., 2016, Programy nauczania jesylka polskiego jako obcego. Poziomy A1-C1 (PNJPJO), Kraków.

19 Marcin Jacoby pisze: „Chiny to kraj smakoszy. Miłość do kuchni w ogóle zresztą łączy wiele kultur azjatyckich. W przeciwieństwie do Europy czy Ameryki, gdzie znajomi spotykaja się często na drinka, w Azji Wschodniej i Południowo-Wschodniej to nie alkohol, a wspólne jedzenie posiłków stanowi platformę nawiązywania, umacniania i rozwijania kontaktów pomiędzy rodzina, przyjaciółmi a dalszymi znajomymi czy partnerami biznesowymi. W Chinach, Japonii, Korei, Wietnamie niemal całe życie społeczne toczy się wokół jedzenia. To temat wspólnych rozmów i wspólnych planów. Przyjaciele gotowi są na bardzo długie i żywe dyskusje dotyczące tego, gdzie wybiorą się razem na lunch” (Jacoby 2016, 297-298). 
Jelonkiewicz M., 2004, Wiedza o Polsce jako element nauczania cudzoziemców jezylea polskiego. Przeglad wybranych materiałów dydaktycznych i pomocniczych, w: Miodunka W.T., red., Kultura w nauczaniu jezyka polskiego jako obcego. Stan obecny - programy nauczania - pomoce dydaktyczne, Kraków.

Li Y., 2012, Po polsku nie tylko sie mówi! Metodyka nauczania kultury w dydaktyce polonistycznej $w$ Chinach, „Postscriptum Polonistyczne”, nr 2 (10).

Lisowski T., 2006, Specyfika nauczania jezyka polskiego na Dalekim Wschodzie. Polonistyka w Hankuk University of Foreign Studies w Seulu, „Postscriptum”, nr 2 (52).

Malejka J., 2008, Potomkowie smoka o sobie samych, czyli o autostereotypie Chinczyków, „Postscriptum Polonistyczne", nr 1 (1).

Malejka J., 2010, Na gteboka wode - o zaletach (i wadach) komunikowania sie z. Chińczykami wytacznie po polsku, w: Spotkania Polonistyk Trzech Krajów - Chiny, Korea, Japonia. Międzynarodowa Konferencja Akademicka, rocznik 2009, Tokio.

Małolepsza M., Szymkiewicz A., 2006, Hurra!!! Po polsku 1, Kraków.

Marcjanik M., 2008, Grzecz̧ność w komunikacji jezylkowej, Warszawa.

Miodunka W.T., 2004, Kompetencja socjokulturowa w nauczaniu polskiego jako obcego. Zarys programu nauczania, w: Miodunka W.T., red., Kultura w nauczaniu jezyka polskiego jako obcego. Stan obecny - programy nauczania - pomoce dydaktyczne, Kraków.

Morcinek B., 2010, Ttumaczenie kultur - oswajanie kultur? Kilka uwag o kuchni, w: Spotkania Polonistyk Trzech Krajów - Chiny, Korea, Japonia. Międzynarodowa Konferencja Akademicka, rocznik 2009, Tokio.

Morcinek-Abramczyk B., 2016, Polski jest prosty! Podreçnik do nanki jezylka polskiego dla osób japońskojezycznych, Katowice.

Prizel-Kania A., Bucko D., Majcher-Legawiec U., Sowa K., 2016, Po polsku po Polsce. Podręrnike do nauczania jezykea polskiego jako obcego oraz kultury polskiej dla poczatkujacych, Kraków.

Stempek I., Stelmach A., Dawidek S., Szymkiewicz A., 2013, Polski krok po kroku 1, Kraków.

Tambor J., 2015, Egrotyzmy kulinarne w $i$ na jezyku Polaków. Rozważania o jedzeniu, mówieniu i pisaniu, w: Spotkania Polonistyk. Trzech Krajów - Chiny, Korea, Japonia. Międzynarodowa Konferencja Akademicka, rocznik 2014/2015, Tokio.

Tambor J., 2018, Pierwsze, drugie i...co dalej, w: Spotkania Polonistyk. Trzech Krajón - Chiny, Korea, Japonia. Miedsynarodowa Konferencja Akademicka, rocznik 2018/2019, Seul.

Wacławek M., Wtorkowska M., 2018a, Powiedz mi, co jesz, a powiem ci, kim jesteś - o kulinariach w Stowenii, w: Grochala B., Dembowska-Wosik I., red., „Acta Universitatis Lodziensis. Kształcenie Polonistyczne Cudzoziemców”, nr 25.

Wacławek M., Wtorkowska M., 2018b, Przezjedzenie do jezyka... polskiego - o kulinariach oczami Polaków i Stoweńców, w: Lech-Kirstein D., red., Bariery i pomosty w jezyku i kulturze, Opole.

Zarzycka G., 2008, Opis pedagogiki zorientowanej na rozwój kompetencji i wrą̇liwośsi interkulturowej, w: Miodunka W.T., Seretny A., red., W poszukiwaniu nowych rozmiazań. Dydaktyka jezyka polskiego jako obcego u progu XXI wieku, Kraków.

Zarzycka G., 2018, Podejście interkulturowe w nauczaniu jezyka polskiego jako obcego. Bilans i perspektywy, w: Tambor J., red. całości, Polonistyka na poczqteu XXI wieku. Diagnozy, koncepcje, perspek.tywy, t. V: Achtelik A., Graboń K., red., W kregu (glotto)dydak.tyki, Katowice.

Żydek-Bednarczuk U., 2015, Spotkanie kultur. Komunikacja i edukacja międzykulturowa w glottodydaktyce, Katowice. 
Jagna Malejka - dr, Wydział Studiów Rosyjskich i Euroazjatyckich, Szanghajski Uniwersytet Studiów Międzynarodowych (School of Russian and Eurasian Studies, Shanghai International Studies University), Szanghaj, Chiny.

Obecnie uczy języka i kultury polskiej na Szanghajskim Uniwersytecie Studiów Międzynarodowych. W Chinach i Japonii przepracowała łącznie ponad 13 lat. Autorka i współautorka artykułów na temat chińskiej grzeczności językowej i form adresatywnych, autostereotypu Chińczyków, zapożyczeń japońskich w polszczyźnie oraz nauczania języka polskiego i kultury polskiej w Azji. Współredagowała wiele publikacji, m.in. tomy pokonferencyjne: Spotkania Polonistyk Trzech Krajów - Chiny, Korea, Japonia (Pekin 2011; Tokio 2015), Obrazkowy słownik języka chińskiego (Pekin 2010), Współczesny język chiński. Podręcznik dla studentów polskojęzycznych (Pekin 2010), Polski jest prosty! Podręcznik do nauki języka polskiego dla osób japońskojęzycznych (Katowice 2016).

Kontakt: jagnamalejka@163.com 